\title{
Physical control of the horizontal patchiness of sea-ice microalgae*
}

\author{
Michel Gosselin ${ }^{1}$, Louis Legendre ${ }^{1}$, Jean-Claude Therriault ${ }^{2}$, \\ Serge Demers ${ }^{2} \&$ Martine Rochet $^{1}$
}

\author{
${ }^{1}$ Département de biologie, Université Laval, Québec, Québec G1K 7P4, Canada \\ ${ }^{2}$ Centre Champlain des Sciences de la Mer, Ministère des Pêches et des Océans, C.P. 15 500,901 Cap Diamant, Québec, Québec \\ G1K 7 Y7, Canada
}

\begin{abstract}
Factors controlling the horizontal distribution of sea-ice microalgae were studied in Southeastern Hudson Bay and adjacent Manitounuk Sound (Canadian Arctic). Both large $(\sim 30 \mathrm{~km})$ and small $(0.3$ to $500 \mathrm{~m})$ scales of variability were investigated. Results showed that salinity was the most important factor controlling large scale distribution of the ice-microalgal biomass, through its effect on the structure of the ice (surface available for colonization). Variation in the thickness of the snow-ice cover, which determines irradiance at the bottom of the ice, was the factor controlling distribution of the algal biomass at smaller scale (diameter of patches of microalgal biomass ranging between 20 and $90 \mathrm{~m}$ ). The relation between ice-algal abundance and snow-ice thickness changed however over the season. At the beginning of the growing season (in April when the bottom-ice irradiance was higher than a minimum critical irradiance), maximum algal biomass was observed under areas covered by the smallest snow depths. Towards the end of the season, when light transmitted through the snow-ice cover increased, maximum algal biomass was observed under areas covered by the deepest snow. This suggests that ice algae have both minimum and maximum critical light levels. The minimum level is the irradiance below which there is no photosynthetic activity $\left(\mathrm{I}_{\min }\right.$ $7.6 \mu$ Einst $\mathrm{m}^{-2} \mathrm{~s}^{-1}$ ) and the maximum level corresponds to the inhibiting light intensity, which may vary during the growth season. The horizontal heterogeneity of the snow-ice cover, which is influenced by wind at the air-ice interface, thus provides diversified bottom-ice habitats where irradiance is compatible or not with the physiological limits of the ice microalgals cells. This results in a strong patchiness in distribution of ice-bottom microalgae.
\end{abstract}

\section{INTRODUCTION}

The spatial distribution of microalgae in the natural environment is most often heterogeneous, as observed in lakes, estuaries, coastal and open ocean areas, etc. This heterogeneity has been attributed to an equilibrium between (1) physical processes (e.g. upwelling, Langmuir circulation, wind or tidal mixing) which, on intermediate scales, tend to homogeneize the aquatic environment, and (2) algal growth processes which, on larger scales, promote heterogeneities in biomass (Skellam 1951, Kierstead \& Slobodkin 1953, Denman \& Platt 1976, Denman et al. 1977).

In ice-covered seas, the horizontal distribution of ice microalgae is also known to be patchy (Bunt \& Lee

\footnotetext{
- Contribution to the program of GIROQ (Groupe interuniversitaire de recherches océanographiques du Québec)
}

1970, Alexander et al. 1974, Horner \& Schrader 1982, Garrison et al. 1983, McConville \& Wetherbee 1983, Clarke \& Ackley 1984). However, the factors controlling this patchiness are still under debate. A number of authors have ascribed the large scale (several $\mathrm{km}$ ) horizontal distribution of the sea-ice algae to processes of ice formation and the associated varying ice structure (Garrison et al. 1983, McConville \& Wetherbee 1983, Poulin et al. 1983, Clarke \& Ackley 1984), while at small scale, snow depth (Alexander et al. 1974, Clasby et al. 1976, Horner \& Schrader 1982) and light intensity at the bottom of the ice (Bunt \& Lee 1970 , Sasaki \& Watanabe 1984) were among the factors invoked.

The present study was designed to test the hypothesis that ice-microalgal patchiness results from physiological responses of the microalgae to some horizontally heterogenous physical factors, against the 
alternative hypotheses of purely biological (e.g. behavioural) or physical (e.g. ice structure) processes. This study covers both large $(\sim 30 \mathrm{~km})$ and small $(0.3$ to $500 \mathrm{~m}$ ) scales, and looks at the relations between environmental factors and microalgal responses at different locations and at different times of the growth season.

\section{MATERIALS AND METHODS}

Sampling was conducted on the first-year ice of southeastern Hudson Bay, off Kuujjuarapik (Fig. 1). In May 1982, a network of sites was sampled around Sta. 1 in Manitounuk Sound. Sta. 1 and Sta. 100, the latter being located in the plume of the Great Whale River, were also sampled twice a week from 30 March to 16 May 1982. In 1983, sampling was at Sta. 253 located in Hudson Bay. Physical characteristics of the station in Manitounuk Sound (Sta. 1) have been described by Poulin et al. (1983). Sta. 100 and 253 were located 13 and $18 \mathrm{~km}$ respectively offshore from the mouth of the Great Whale River, at depths of 26 and $102 \mathrm{~m}$. Two different sampling regimes were used in 1982 and 1983, to study the horizontal distributions of the ice microflora.

Sampling design and data analysis in 1982. In 1982, ice cores (Sipre ice corer: $7.5 \mathrm{~cm}$ int. diam.) were taken at 27 sites distributed along 5 transects radiating from
Sta. 1 in Manitounuk Sound. The distance between sites varied from a minimum of $0.3 \mathrm{~m}$ to a maximum of $480 \mathrm{~m}$. This sampling regime was used to assess the relations between the values of each sampled variable and their omnidirectional horizontal distributions. At each site, snow depth and ice thickness were measured, and the bottom $20 \mathrm{~cm}$ of the ice core were collected. Ice thickness concerns here the hardened sea ice as there was no brash ice layer, which consists of unconsolidated ice crystals accumulating beneath the hard sea ice, as found in some areas of Antarctica (e.g. Bunt 1963, Bunt \& Lee 1970). A subsample of the melted ice was filtered on Whatman GF/C for fluorometric determination of chlorophyll a (Yentsch \& Menzel 1963), after 1 h extraction in $100 \%$ methanol at $0^{\circ} \mathrm{C}$ (Holm-Hansen \& Riemann 1978). Another subsample was preserved with acid Lugol for cell enumeration. Salinity of melted ice was determined using a Hytech 6220 salinometer. In addition, ice cores were sampled twice a week at both Sta. 1 and 100, and treated as described above.

Data were log transformed when their distributions were significantly different from normal ( $p>0.05$; Kolmogorov-Smirnov test: Conover 1973). The 2-dimensional horizontal distributions of the variables were analysed by spatial autocorrelation (Cliff \& Ord 1973, 1981, Sokal \& Oden 1978, Legendre \& Legendre 1984, Mackas 1984), using Moran's (1950) $I$. This coefficient is somewhat similar to Pearson's coefficient of linear

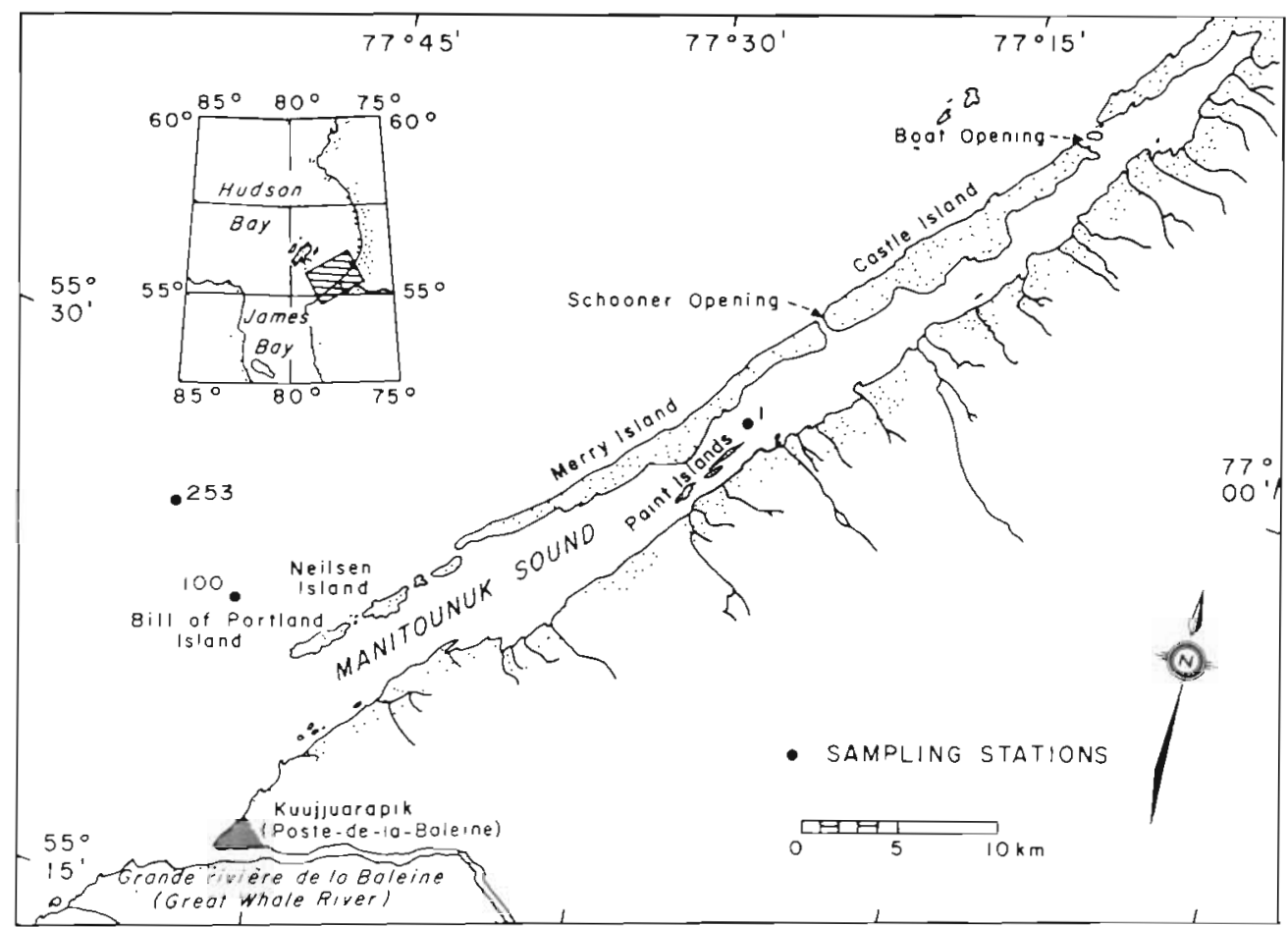

Fig. 1. Location of sampling stations in Manitounuk Sound (Sta. 1, 1982), in the plume of the Great Whale River (Sta. 100, 1982) and in Hudson Bay (Sta. 253, 1983) 
correlation. For a class of distances (D) between sites (e.g. all the sites distant from each other by about $0.3 \mathrm{~m}$, or $0.5 \mathrm{~m}$, or . . $480 \mathrm{~m}$ : see Fig. 3), Moran's I measures how random is the spatial distribution of the studied variable. Cliff \& Ord $(1973,1981)$, Sokal \& Oden (1978) and Legendre \& Legendre (1984) explain how to test the significance of Moran's $I$. When $I$ exceeds the critical value (positive or negative), the hypothesis of a random spatial distribution (i.e. no spatial autocorrelation) is rejected at the specified level of significance. As we did not have a priori hypotheses as to the signs of the spatial autocorrelation coefficients $I$, our tests of significance were 2-tailed. The results are presented as correlograms, where $I$ (D) is plotted as a function of the classes of distances (D) between sites.

Sampling design and data analysis in 1983. In 1983. ice cores were taken from sampling sites $5 \mathrm{~m}$ apart along three $\sim 500 \mathrm{~m}$ long transects. On 15-17 April and 3-4 May the transects were perpendicular to snowdrifts; on 6-7 May the transect was perpendicular to that of 3-4 May (Site $250 \mathrm{~m}$ of 3-4 May corresponded to Site $165 \mathrm{~m}$ of 6-7 May: Fig. 2). This sampling regime was used to assess the relations between the values of each sampled variable and their unidirectional horizontal distributions. At each site, snow depth and ice thickness were measured, as well as the photosynthetically active irradiance (Biospherical Scalar Irradiance Meter) above $\left(I_{0}\right)$ and under $\left(I_{z}\right)$ the ice. Ice cores were sampled as in 1982 . The bottom $2 \mathrm{~cm}$, in which almost all the microalgal biomass was concentrated, were cut from the ice cores and melted; the water was then filtered on Whatman GF/C for fluorometric determination of chlorophyll a (Yentsch \& Menzel 1963), after 24 h extraction in $90 \%$ acetone. The filtrate was frozen for later determination of nutrients using a Technicon autoanalyser (Strickland \& Parsons 1972). Then, the next $5 \mathrm{~cm}$ above were cut and melted for salinity determination. In addition, under-ice water was collected every 10th sampling site using a $1.7 \mathrm{l}$ Niskin bottle. Salinity of the $5 \mathrm{~cm}$ ice-core subsamples and of the under-ice water was determined as in 1982.

$15-17$ APRIL

1983

ing

I

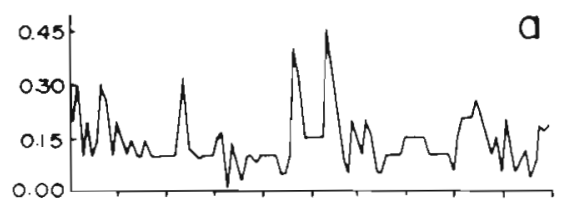

a

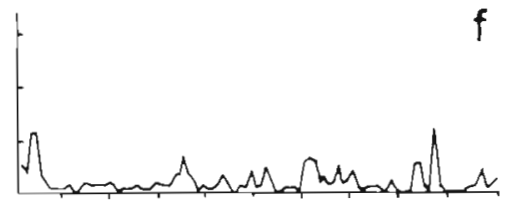

${ }^{2.20}[\quad b$
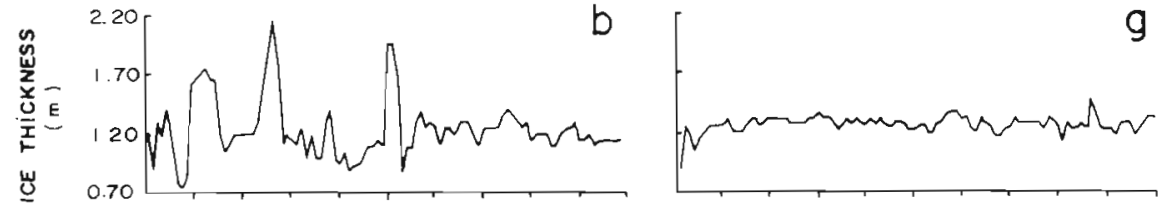

g

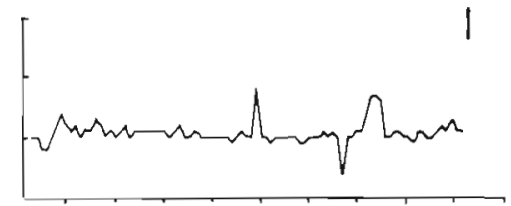

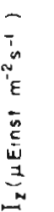
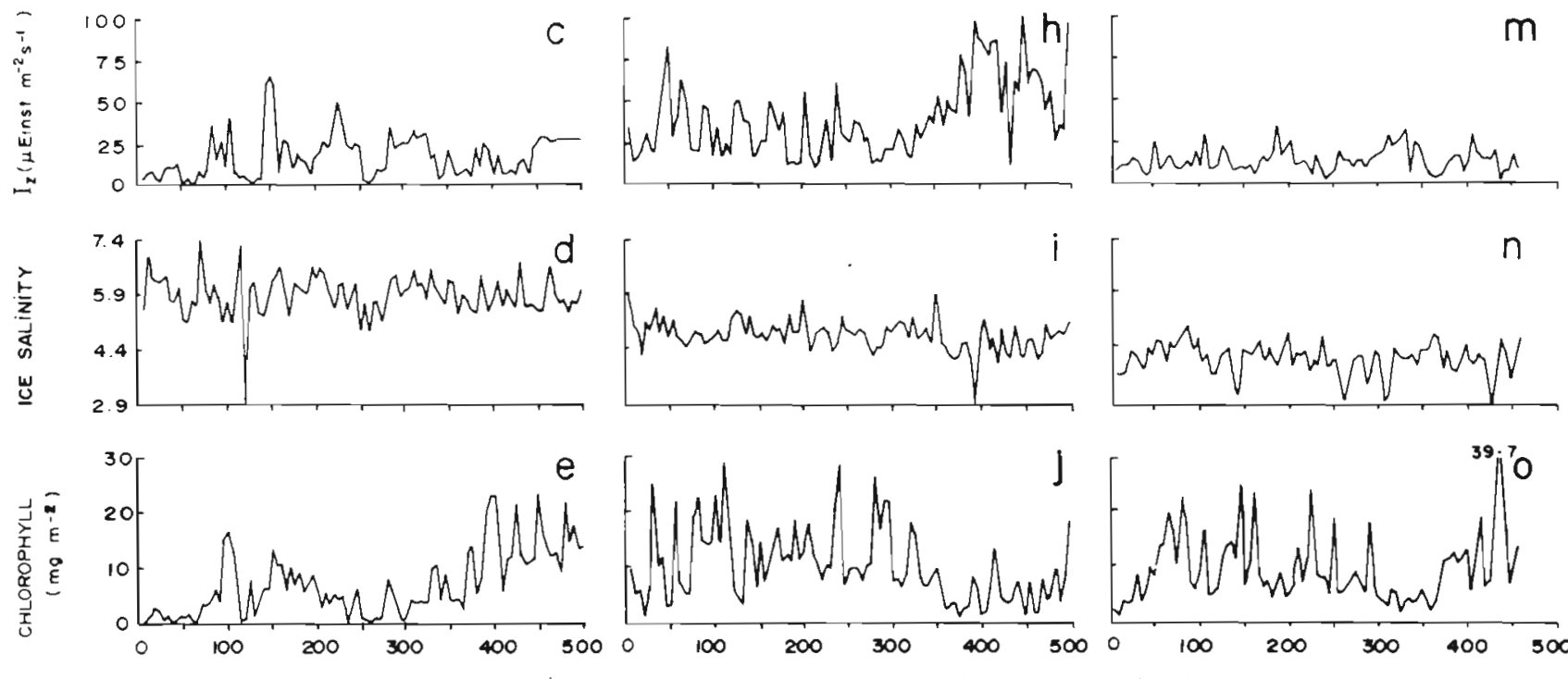

POSITION ALONG THE TRANSECTS $(\mathrm{m})$

Fig. 2. Spatial variations of physical and biological variables sampled along transects at Sta. 253, in 1983 
Sea-ice microalgae were sampled on 13 different occasions in April and May 1983, at Sta. 253 near the transects. Using an especially designed 2.01 sampler (Maestrini et al. unpubl.), we collected the interstitial water flowing from the ice together with the microalgae from the ice-water interface. The under-ice irradiance $\left(I_{2}\right)$ and the chlorophyll a concentrations were determined as described above. Microalgal photosynthetic rates versus irradiance were measured using an incubator described by Lewis \& Smith (1983), under the light transmitted through commercial plexiglass, in order to simulate the light conditions prevailing under the ice (light predominantly blue-green: Maykut \& Grenfell 1975). Photosynthetic parameters, normalized per unit chlorophyll $a$, were estimated according to the equations of Platt et al. (1980) using a Gauss-Newton algorithm (Jennrich \& Sampson 1968). These parameters were the photosynthethic capacity $\left(\mathrm{P}_{\text {max }}^{\mathrm{B}}\right)$, the photosynthetic efficiency $\left(\alpha^{\mathrm{B}}\right)$, the photoinhibition parameter $\left(\beta^{B}\right)$ and the saturating irradiance $\left(\mathrm{I}_{\mathrm{m}}\right)$.

Data series were transformed (logarithmic or square root transformation) when their distributions were significantly different from normal ( $p>0.05$; KolmogorovSmirnov test: Conover 1973). They were then detrended by moving averages on 7 (15-17 April and 3-4 May) or 5 (6-7 May) data points, the stationary residual data series being computed by subtracting the moving-average trend from the original data series. The results of harmonic analysis (Jenkins \& Watts 1968) were then plotted as Schuster's periodograms, in order to identify dominant periodicities in each detrended data series. The same formula as in Demers \& Legendre (1981) was used for computing the critical values of the periodograms. Relations between pairs of variables were investigated by linear cross-correlations between the detrended data series (Legendre \& Legendre 1984). Mann-Whitney 1 -way analyses of variance (Siegel 1956) were used to compare the values from the 2 different sampling months for the photosynthetic parameters and the under-ice irradiance $\left(I_{z}\right)$.

Path analysis (Sokal \& Rohlf 1981) was used to explore causal relations between physical variables (snow depth, ice thickness and under-ice irradiance) and the ice-microalgal biomass (chlorophyll a). Path analysis is an extension of multiple linear regression, where hypotheses as to causal relations among variables can be assessed. To do so, linear equations were written in order to specify the causal order among variables. In Fig. 7, for example, these equations are:

chlorophyll $=p_{11}$ snow depth $+p_{12}$ ice thickness irradiance $I_{2}=p_{21}$ snow depth $+p_{22}$ ice thickness + $p_{23}$ chlorophyll

Path coefficients $p$ are then estimated by multiple linear regressions on standardized variables. The coefficients are interpreted in terms of their signs and relative magnitudes, rather than their individual statistical significance (Sokal \& Rohlf 1981).

\section{RESULTS}

At the Manitounuk Sound network of sites (1982), chlorophyll concentrations (Table 1) were more than 1 order of magnitude Iower than along the Hudson Bay transects (1983). Comparison of Sta. 1 (Manitounuk Sound) and 100 (plume of the Great Whale River) in April-May 1982 indicates that this difference in biomass is a constant feature of the area. The average chlorophyll concentration at Sta. 1 was $0.3 \mathrm{mg} \mathrm{m}^{-2}$, compared to $1.9 \mathrm{mg} \mathrm{m}^{-2}$ at Sta. 100. The horizontal distribution of biomass (including cell numbers, in 1982) was quite heterogeneous, in both Manitounuk Sound and Hudson Bay (Table 1 and Fig. 2e, j, o).

Moran's I correlograms were used to characterize the horizontal 2-dimensional structure of chlorophyll (Fig 3a) and microalgal cells (Fig. 3b), in Manitounuk

Table 1. Range (mean) of physical and biological variables, sampled in Manitounuk Sound and Hudson Bay

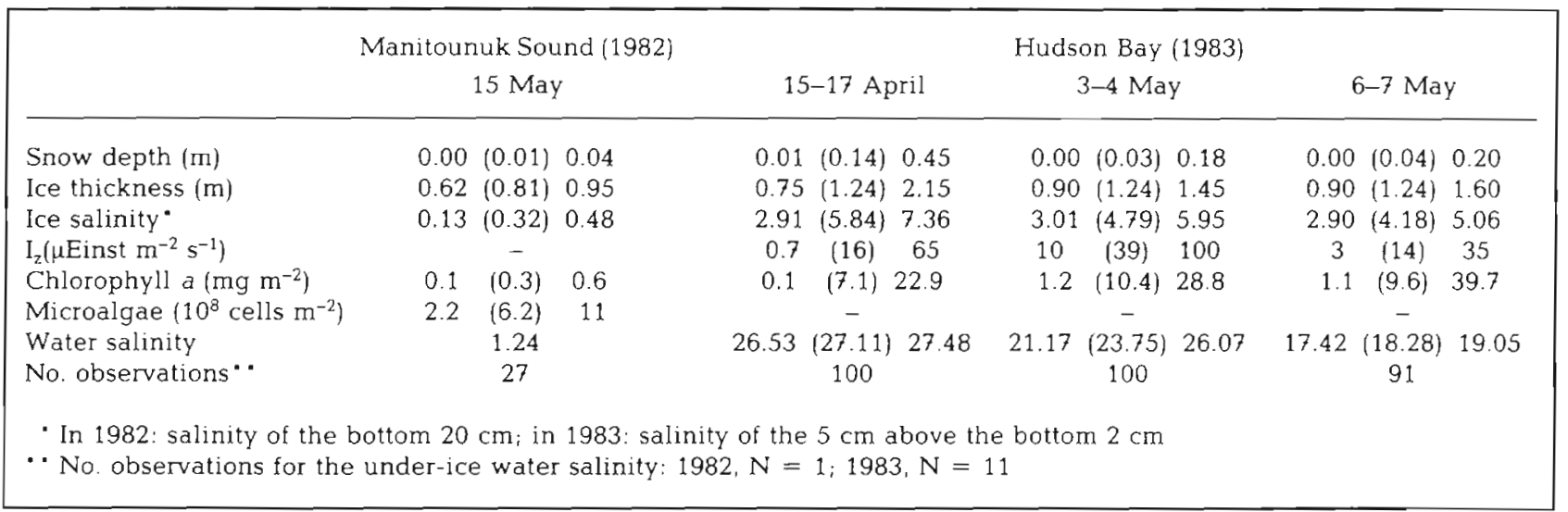


Sound. Significant positive values were found for the $10 \mathrm{~m}$ class of distances, and significant negative values for the 46 and $63 \mathrm{~m}$ classes of distance. This indicates that the average radius of the microalgal patches at the bottom of the ice was probably between 10 and $46 \mathrm{~m}$, where the first zero of the correlograms is observed (Sokal 1979, Legendre \& Legendre 1984).

The Hudson Bay transects showed large variability for all the variables (Fig. 2). In April, the transect was perpendicular to the snow-drifts. The periodograms (Fig. 4) show significant periodic horizontal structures of about $20 \mathrm{~m}$ for both snow depth (Fig. 2a \& 4a) and under-ice irradiance (Fig. 2c \& 4c), and of about $30 \mathrm{~m}$ for the concentration of chlorophyll (Fig. $2 e \& 4 e$ ). Ice thickness (Fig. 2b) and ice salinity (Fig. 2d) did not show any significant periodic horizontal variability (Fig. 4b, d). Cross-correlations evidenced an inverse significant relation between under-ice irradiance and ice thickness (Fig. 5b), but no significant relation with snow depth (Fig. 5a). Chlorophyll increased with higher under-ice irradiance, with a periodicity of about $20 \mathrm{~m}$ (Fig. 5c).

On 3-4 May, the transect was perpendicular to the
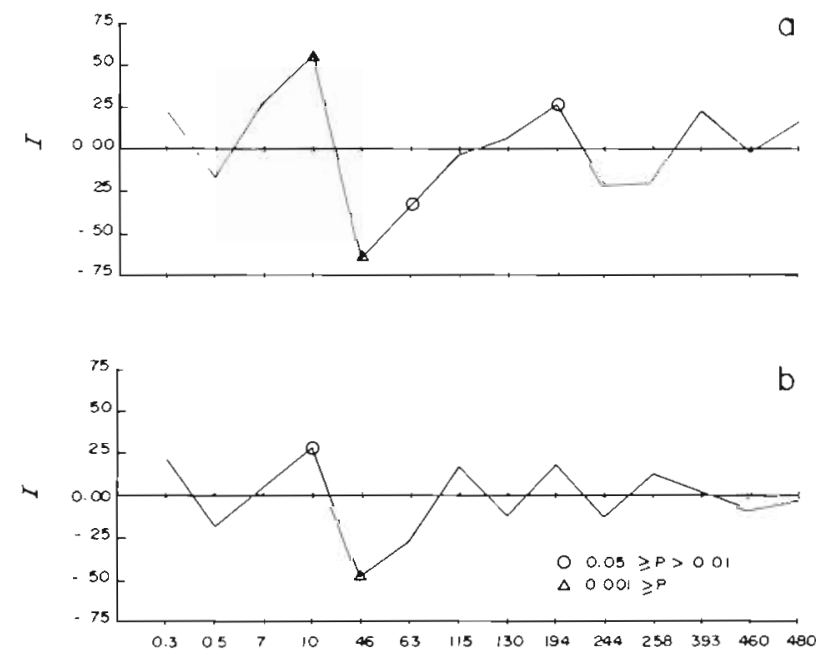

CLASSES OF DISTANCES BETWEEN SITES ( $\mathrm{m}$ )

Fig. 3. Moran's $I$ as a function of classes of distances between sites in 1982, for (a) chlorophyll a concentration and (b) number of cells in the bottom $20 \mathrm{~cm}$ of the ice. Mathematical expectancy of $I$, under the hypothesis of a completely random spatial distribution, is not zero but $E(I)=-0.0385$. Significance tests are 2-tailed

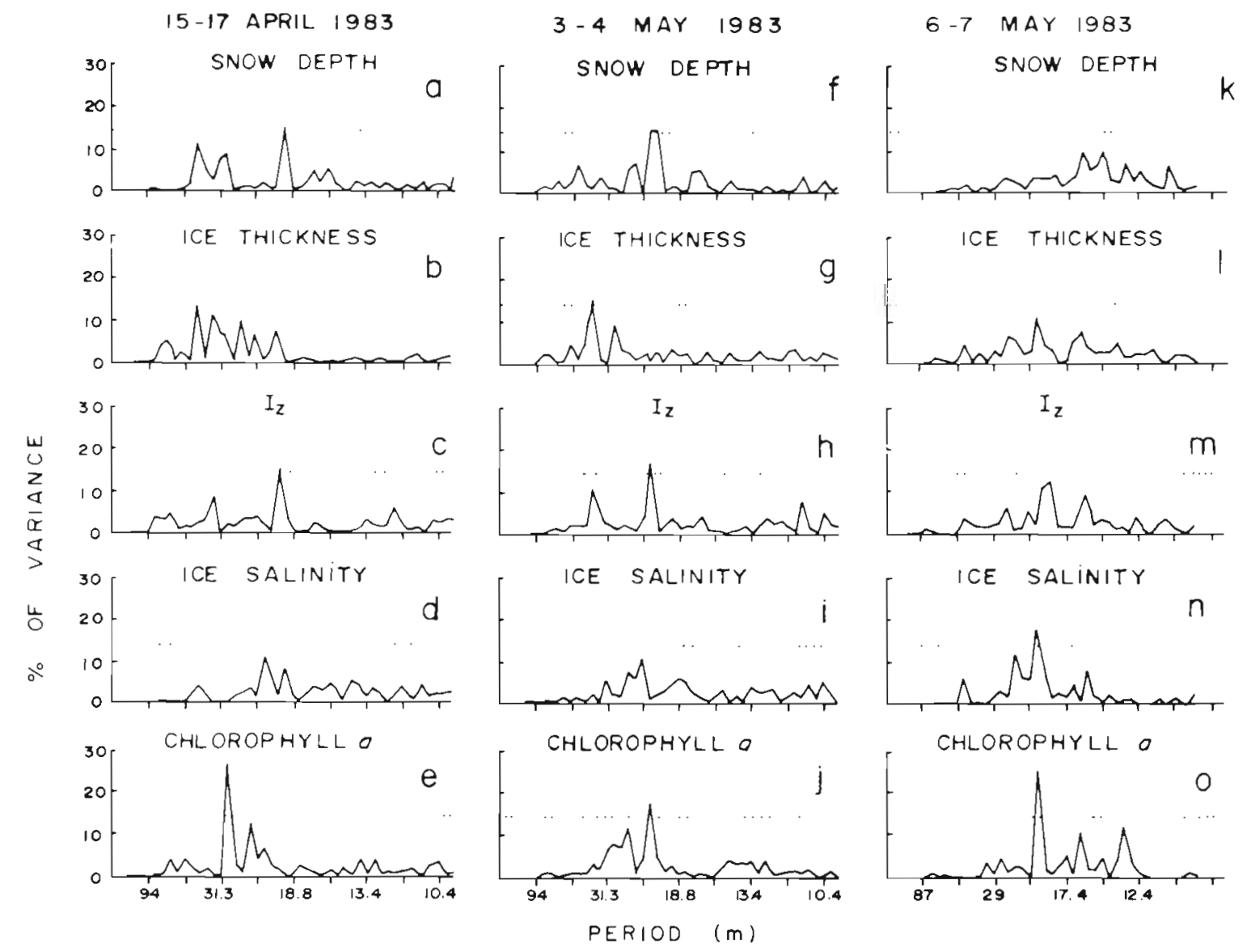

Fig. 4. Periodograms resulting from the harmonic analyses of variables in Fig. 2; (a-e) 15-17 April; (f-j) 3-4 May; (k-o) 6-7 May 1983. Horizontal dotted lines: critical values $(\alpha=0.05)$ 
snow-drifts, as in April. Harmonic analysis evidenced significant periodic horizontal structures of about $20 \mathrm{~m}$ for the snow depth (Fig. $2 f$ \& 4f), the under-ice irradiance (Fig. $2 \mathrm{~h} \& 4 \mathrm{~h}$ ) and the concentration of chlorophyll a (Fig. $2 \mathrm{j} \& 4 \mathrm{j}$ ), and of about $35 \mathrm{~m}$ for the ice thickness (Fig. $2 \mathrm{~g} \& 4 \mathrm{~g}$ ). As in April, no significant periodic variations were evidenced in ice salinity (Fig. $2 i \& 4 i)$. The under-ice irradiance was inversely correlated (Fig. 5e) with ice thickness, as in April (Fig. 5b), and also with snow depth (Fig. 5d). Contrary to April (Fig. 5c), chlorophyll increased in early May as underice irradiance decreased, with a peridocity of about $20 \mathrm{~m}$ (Fig. 5f).

The 6-7 May transect was perpendicular to that of 3-4 May. Significant periodic horizontal structures of about $20 \mathrm{~m}$ were found for both bottom-ice salinity (Fig. 2n \& 4n) and chlorophyll concentration (Fig. 2o \& $40)$. No significant periodic variations were found for snow depth (Fig. 2k), ice thickness (Fig. 2l) or underice irradiance (Fig. 2m). Cross-correlations indicated that the under-ice irradiance was inversely correlated with both snow depth and ice thickness (Fig. $5 g$, h), as had been observed for the transect of 3-4 May (Fig. 5d, e). Contrary to the 2 other transects, there was no significant cross-correlation between chlorophyll and under-ice irradiance (Fig. 5i), but there was a significant increase of chlorophyll with higher bottom-ice salinity, on the scale of about $20 \mathrm{~m}$ (Fig. 6).

The 3 transects showed positive linear correlations between chlorophyll and phosphate concentrations $(r=0.67,0.64$ and $0.43 ; p \leq 0.001)$. However, such correlations may have resulted from cell lysis during the preparation for nutrient analysis (e.g. Clarke \& Ackley 1984, in the Antarctic marginal ice zone), so that they with not be discussed further.

Mann-Whitney 1 -way analyses of variance showed a significant effect $(\mathrm{p} \leq 0.05)$ of the sampling months (April and May 1983) on some photosynthetic parameters and the under-ice irradiance $\left(\mathrm{I}_{z}\right)$. The photosynthetic capacity $\left(\mathrm{P}_{\text {max }}^{\mathrm{B}}\right)$, the photosynthetic efficiency $\left(\alpha^{\mathrm{B}}\right)$, the photoinhibition parameter $\left(\beta^{B}\right)$ and the under-ice irradiance $\left(I_{z}\right)$ were higher in May than in April (Table
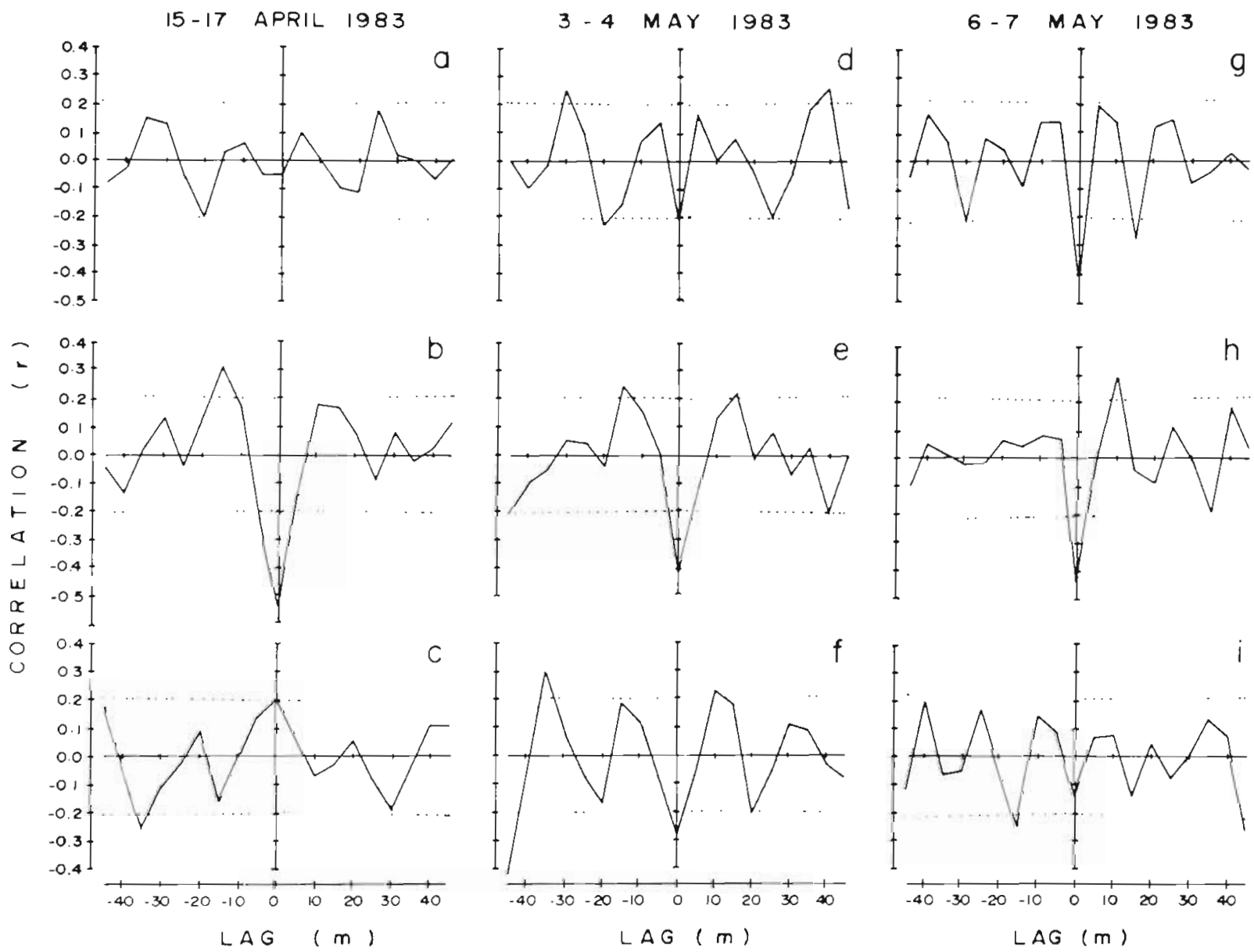

Fig. 5. Linear cross-correlations between $(a, d, g) I_{z}$ and snow depth, $(b, e, h) l_{z}$ and ice thickness, and $(c, f, i) I_{z}$ and chlorophyll a concentration in the bottom $2 \mathrm{~cm}$ of the ice; (a-c) 15-17 April; (d-f) 3-4 May; (g-i) 6-7 May 1983. Horizontal dotted lines: confidence interval $(\alpha=0.05)$ 


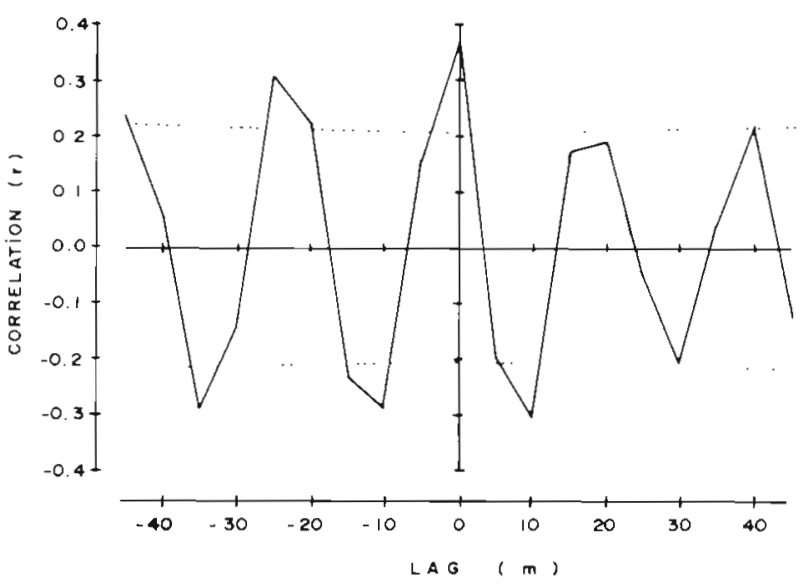

Fig. 6. Linear cross-correlation between sea-ice salinity and chlorophyll a concentration in the bottom $2 \mathrm{~cm}$ of the ice, 6-7 May 1983. Horizontal dotted lines: confidence interval ( $\alpha=$ 0.05)

2). There was no significant difference between the sampling months for the saturating irradiance $\left(I_{m} ; \mathrm{p}=\right.$ $0.735)$

\section{DISCUSSION}

\section{Physical control of large-scale distribution of ice microalgae}

At the large scale $(\sim 30 \mathrm{~km})$, which corresponds to the distance covered by the sampling stations (Fig. 1), there exists a general gradient in chlorophyll concentrations, the average value decreasing from $\sim 7$ to 10 $\mathrm{mg} \mathrm{m}^{-2}$ in Hudson Bay (Table 1 ) to $\sim 2 \mathrm{mg} \mathrm{m}^{-2}$ in the plume of the Great Whale River (Sta. 100, in AprilMay 1982), and to $0.4 \mathrm{mg} \mathrm{m}^{-2}$ in Manitounuk Sound (Sta. 1, in April-May 1982). This gradient in biomass parallels the salinity of the underlying waters, which decreases, on average, from $\sim 17$ to $27 \%$ in Hudson Bay (Table 1 ) to $~ 15 \%$ in the plume of the River, and to $\sim 4 \%$ in the Sound. Salinity and chlorophyll values at some intermediate stations (Poulin et al. 1983) support the existence of this general gradient.

According to Poulin et al. (1983), the salinity of the underlying water influences both (a) the structure of the ice (surface available for colonization by the cells) and thus the settlement efficiency of the microalgae, and (b) the ice thickness, which changes the irradiance at the bottom of the ice. These 2 factors would consequently control the ice-microalgal biomass in coastal waters. The control of ice microalgae by ice thickness is however unlikely, since the extinction coefficient of the ice increases with its salinity (Davis \& Munis 1973, Lane 1975). It is therefore probably through the structure of the ice, rather than its optical properties, that salinity controls the large-scale horizontal distribution of ice-microalgal biomass.

\section{Responses of ice microflora to seasonal variations of in situ irradiance}

Cross-correlations have shown (Fig. 5) that the under-ice irradiance $\left(I_{z}\right)$ is simultaneously related to snow depth, ice thickness and the concentration of seaice microalgae. It could be concluded from these relations that, at the scale of the microalgal patches, the horizontal variability in snow-ice cover is transferred to the sea-ice microflora through the agency of underice irradiance. Such a conclusion, however, would be incorrect since the under-ice irradiance is measured below the ice-microalgal layer, so that $I_{z}$ partly results from the concentration of microalgae in the ice. A more appropriate causal model would be as schematized by the path diagrams of Fig. 7. In this model, the horizontal variability in the snow-ice cover causes changes in bottom-ice irradiance, that influence the growth of ice microalgae. When path coefficients (Sokal \& Rohlf 1981) are computed by multiple regressions on standardized variables, it becomes evident that the responses of microalgae to the thickness of the snowice cover change as the season progresses (Fig. 7). In April, a thicker snow-ice cover was probably responsible for the lower chlorophyll concentrations (negative path coefficients), while in May, it resulted in higher chlorophyll concentrations (positive path coefficients). This difference can be attributed to the photosynthetic

Table 2. Mean (standard deviation) photosynthetic parameters of the sea-ice microalgae, measured under blue-green light in April and May 1983 at Sta. 253

\begin{tabular}{|c|c|c|}
\hline & 10-30 April & 1-10 May \\
\hline $\begin{array}{l}\mathrm{P}_{\max }^{\mathrm{B}}\left(\mathrm{mg} \mathrm{C}[\mathrm{mg} C \mathrm{Chl} a]^{-1} \mathrm{~h}^{-1}\right) \\
\alpha^{\mathrm{B}}\left(\mathrm{mgC}[\mathrm{mg} \mathrm{Chl} \mathrm{a}]^{-1}\left[\mu \text { Einst } \mathrm{m}^{-2} \mathrm{~s}^{-1}\right]^{-1} \mathrm{~h}^{-1}\right) \\
\left.\beta^{\mathrm{B}}(\mathrm{mgC} \mathrm{mg} \mathrm{Chl} a]^{-1}\left[\mu \text { Einst } \mathrm{m}^{-2} \mathrm{~s}^{-1}\right]^{-1} \mathrm{~h}^{-1}\right) \\
\mathrm{I}_{\mathrm{m}}\left(\mu \text { Einst } \mathrm{m}^{-2} \mathrm{~s}^{-1}\right) \\
\mathrm{I}_{2}\left(\mu \text { Einst } \mathrm{m}^{-2} \mathrm{~s}^{-1}\right) \\
\text { No. observations }\end{array}$ & $\begin{aligned} 1.8 & (0.9) \\
0.11 & (0.07) \\
0.005 & (0.004) \\
69 & (20) \\
10 & (7) \\
10 & \end{aligned}$ & $\begin{aligned} 5.2 & (2.1) \\
0.32 & (0.13) \\
0.011 & (0.003) \\
64 & (1.3) \\
30 & (9) \\
3 & \end{aligned}$ \\
\hline
\end{tabular}


response of microalgae to the seasonal increase in irradiance.

The only ice irradiance measurement available is $I_{z}$ the under-ice irradiance. It must be remembered that $I_{2}$ underestimates the bottom-ice irradiance, the degree of this underestimation increasing with the concentration of ice-microalgae. A positive correlation between chlorophyll and $\mathrm{I}_{z}$, as in April (Fig. 5c), therefore indicates a very strong positive response of sea-ice microalgae to bottom-ice irradiance. In April, stations where $I_{z}<4 \mu$ Einst $\mathrm{m}^{-2} \mathrm{~s}^{-1}$ (Fig. 2c) have very low chlorophyll concentrations (Fig. 2e), while those where $\mathrm{I}_{2}>4 \mu$ Einst $\mathrm{m}^{-2} \mathrm{~s}^{-1}$ show chlorophyll concentrations that increase with $I_{z}$. The critical under-ice irradiance 4 $\mu$ Einst $\mathrm{m}^{-2} \mathrm{~s}^{-1}$, below which no biomass seemed to develop, is very similar to that $\left(7.6 \mu\right.$ Einst $\left.\mathrm{m}^{-2} \mathrm{~s}^{-1}\right)$ published by Gosselin et al. (1985) for Manitounuk Sound in 1982. Using 17 values from the literature, Richardson et al. (1983) calculated that the mean minimum photon flux density for the growth of Bacillariophyceae was $6.4 \mu$ Einst $\mathrm{m}^{-2} \mathrm{~s}^{-1}(\mathrm{SE}=0.9)$. They also indicated that the minimum value may actually be lower than reported. Our observed critical minimum irradiance values for bottom-ice microalgae (mainly pennate diatoms) therefore correspond well to known values for this taxonomic group

The photosynthetic characteristics of the sea-ice microalgae changed with time: from April to May (Table 2 ), both the photosynthetic capacity $\left(P_{\max }^{B}\right)$ and efficiency $\left(\alpha^{\mathrm{B}}\right)$ increased as well as the under-ice irradiance $\left(I_{z}\right)$, which suggests photoadaptation; the same is true for the photoinhibition parameter $\left(\beta^{B}\right)$, which indicates higher susceptibility to high light intensities in May. The ice microalgae were thus potentially very susceptible to photoinhibition in May, when $I_{z}$ (and therefore the bottom-ice) irradiance was sometimes higher (Fig. 2h) than the saturating irradiance $\left(\mathrm{I}_{\mathrm{m}}=64 \mu\right.$ Einst $\left.\mathrm{m}^{-2} \mathrm{~s}^{-1}\right)$.
In terms of horizontal distribution of microflora, the differences in photosynthetic characteristics of the microalgae, combined with the seasonal irradiance increase, explain why a thinner snow-ice cover led to higher microalgal biomass in April, while it resulted in lower biomass in May (Fig. 7). Areas with thinner cover, which were favourable for the development of microalgal patches in April (bottom-ice irradiance $>\mathrm{I}_{\text {crut. min. }}$ ), became adverse to ice microalgae in May

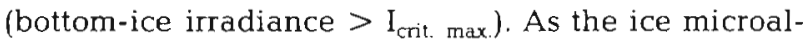
gae progressively adapt their photosynthetic characteristics to the bottom-ice light environment, the actual

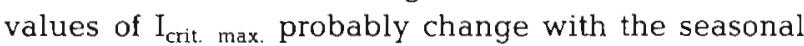
increase in irradiance.

\section{Physical control of small-scale patchiness}

Horizontal differences in the thickness of the snowice cover determine part of the horizontal heterogeneity of the ice-microalgal biomass (Fig. 7). Changes in ice thickness are obviously much slower than changes in snow depth and, consequently, snow depth is much more variable than ice thickness in both space and time (Table 1). In addition to its seasonal changes, snow depth is subjected to short-term variations since its spatial distribution is controlled by the tangential drag exerted by the wind at the air-ice interface. These short-term variations in the snow cover can influence the sea-ice microalgae by rapidly changing the bottom-ice irradiance.

In open waters, high winds have, first, a tendency to increase small-scale phytoplankton structures by breaking up larger patches into smaller patches, before completely eliminating them (Therriault et al. 1978, Levasseur et al. 1983). At the air-ice interface, on the contrary, the effect of the wind is to increase the patchiness of the sea-ice microflora, by changing the
Fig. 7. Path diagrams of possible causal relations (arrows) between snow depth, ice thickness, chlorophyll a concentration and under-ice irradiance
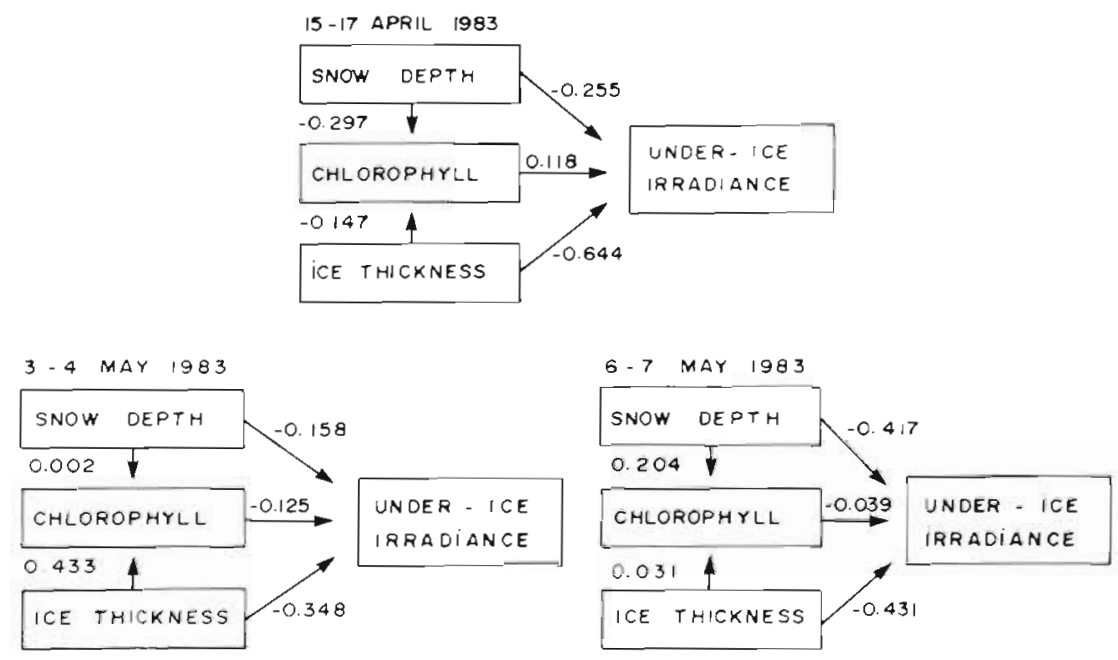
snow drift distribution and consequently the bottomice irradiance.

Snow depth decreased significantly from April to May (Table 1), with the result that, relative to ice thickness, the importance of snow cover for the ice microalgae should decrease from April to May. This is exactly what the path analyses show (Fig. 7), since the April coefficient between snow and chlorophyll is larger than the coefficient between ice and chlorophyll, while the reverse occurs for the transect perpendicular to snow-drifts on 3-4 May (Fig. 7). In May however, even small changes in snow depth might prove very significant for the microalgae, as they can provide protection from photoinhibition (bottomice irradiance $<I_{\text {crit. max. }}$ ). Transects perpendicular to snow-drifts, in both April and May, did show significant periodic horizontal structures of about $20 \mathrm{~m}$ in snow depth (Fig. 4a, f), that can account for part of the microalgal patchiness (Fig. $4 \mathrm{e}, \mathrm{j}$ ) through the agency of bottom-ice irradiance (Fig. 7). In accordance with the model in which snow depth should be random if measured along a transect between parallel snow-drifts, the second transect in May 1983 did not show any significant periodicity in snow depth (Fig. $4 \mathrm{k}$ ). Microalgae along this transect were however distributed in patches (Fig. 40) despite the lack of spatial heterogeneities in the snow-ice cover (Fig. 4k, l). In this last case, microalgal patchiness was related to the spatial distribution of bottom-ice salinity (Fig. 6). The rate of change of bottom-ice salinity caused by gravity drainage or flushing (Cox \& Weeks 1975) or by another desalination mechanism increased during the season from $0.06 \mathrm{~d}^{-1}$ (15-17 April to 3-4 May) to $0.20 \mathrm{~d}^{-1}$ (3-4 May to 6-7 May), without however modifying the thickness of the ice (Table 1). On 6-7 May, the positive relation between the spatial distribution of bottom-ice salinity and chlorophyll (Fig. 6) suggests that both the liquid brine and the microalgae were simultaneously drained from the ice into the underlying water. During the period of ice melt and associated decay of the bottom-ice interface, the horizontal variability of the microalgae is therefore perhaps mainly governed by the thermal properties of the snow-ice cover.

In Manitounuk Sound and southeastern Hudson Bay, the ice microalgae are thus distributed in patches of about 20 to $90 \mathrm{~m}$ in diameter. This patchiness seems to be partly controlled by snow depth, which is influenced by the wind. The horizontal heterogeneity of the snow-ice cover contributes to extend the growth season for sea-ice microalgae, by providing bottom-ice habitats where irradiance is compatible with the photosynthetic limits of the cells $\left(\mathrm{I}_{\text {cnt. min. }}<\right.$ bottom-ice irradiance $<I_{\text {crit. max. }}$.

It can be hypothesized that the existence of minimum and maximum critical irradiances for ice- microalgal photosynthesis could perhaps also explain some of the large-scale variations of sea-ice microalgae, in environments where sea water salinity is relatively uniform. As these critical irradiances would probably not be reached simultaneously over a large area, spatial heterogeneities could perhaps lead to various developmental stages of the ice-microalgal populations, as proposed for phytoplankton by Steele (1978).

Acknowledgements. This research was funded by the Natural Sciences and Engineering Research Council of Canada (strategic and individual research grants to L. L.) and by the Department of Fisheries and Oceans (Champlain Centre for Marine Sciences and Surveys, Québec). It would not have been possible to conduct this project without the logistic support of the Société d'Énergie de la Baie James and of the Centre d'études nordiques (CEN), Université Laval. We acknowledge the invaluable assistance of C. Côté, superintendent at the Kuujjuarapik field station of the CEN. We are especially indebted to $M$. Dubé, A. Gagné, S. Y. Maestrini and $J$. Therrien for their assistance in the field, to L. BérardTherriault for cell enumeration, and to P. Legendre for the spatial autocorrelation program. Figures were drawn by $\mathrm{L}$. Corriveau and L. Roy-Saint-Pierre.

\section{LITERATURE CITED}

Alexander, V., Horner, R., Clasby, R. C. (1974). Metabolism of Arctic sea ice organisms. Rep. Inst. Mar. Sci. Univ. Alsaka R7 4-4: $1-120$

Bunt, J. S. (1963). Diatoms of Antarctic sea ice as agents of primary production. Nature, Lond. 199: 1255-1257

Bunt, J. S., Lee, C. C. (1970). Seasonal primary production in Antarctic sea ice at McMurdo Sound in 1967. J. mar. Res. 28: $304-320$

Clarke, D. B., Ackley, S. F. (1984). Sea ice structure and biological activity in the Antarctic marginal ice zone. J. geophys. Res. 89: 2087-2095

Clasby, R. C., Alexander, V., Horner, R. (1976). Primary productivity of sea-ice algae. In: Hood, D. W., Burrell, D. C. (ed.) Assessment of the Arctic marine environment: selected topics. Inst. Mar. Sci., Univ. Alaska, Fairbanks, p. 289-304

Cliff, A. D., Ord., J. K. (1973). Spatial autocorrelation. Pion Limited, London

Cliff, A. D., Ord., J. K. (1981). Spatial processes: models and applications. Pion Limited, London

Conover, W. J. (1973). Practical nonparametric statistics. John Wiley and Sons, New York

Cox, G. F. N., Weeks, W. F. (1975). Brine drainage and initial salt entrapment in sodium chloride ice. U.S. Army Cold Regions Res. and Eng. Lab. Research report 345: 1-46

Davis, H., Munis, R. H. (1973). Effect of salinity on the optical extinction of sea ice at 6328A. U.S. A.rmy Cold Regions Res. and Eng. Lab. Research report 308: 1-15

Demers, S., Legendre, L. (1981). Mélange vertical et capacité photosynthétique du phytoplancton estuarien (estuaire du Saint-Laurent). Mar. Biol. 64: 243-250

Denman, K. L., Platt, T. (1976). The variance spectrum of phytoplankton in a turbulent ocean. J. mar. Res. 34: 593-601

Denman, K. L., Okubo, A., Platt, T. (1977). The chlorophyll 
fluctuation spectrum in the sea. Limnol. Oceanogr. 22 1033-1038

Garrison, D. L., Ackley, S. F., Buck, K. R. (1983). A physical mechanism for establishing algal populations in frazil ice. Nature, Lond. 306: 363-365

Gosselin, M., Legendre, L., Demers, S., Ingram, R. G. (1985). Responses of sea ice microalgae to climatic and fortnightly tidal energy inputs (Manitounuk Sound, Hudson Bay) Can. J. Fish. Aquat. Sci. 42: 999-1006

Holm-Hansen, O., Riemann, B. (1978). Chlorophyll a determination: improvements in methodology. Oikos 30:438-447

Horner, R., Schrader, G. C. (1982). Relative contributions of ice algae, phytoplankton and benthic microalgae to primary production in nearshore regions of the Beaufort Sea. Arctic 35: 485-503

Jenkins, G. M., Watts, D. G. (1968). Spectral analysis and its applications. Holden-Day, San Francisco

Jennrich, R. I., Sampson, P. F. (1968). Application of stepwise regression to nonlinear least squares estimation. Technometrics 10: 63-67

Kierstead, H., Slobodkin, L. B. (1953). The size of water masses containing plankton blooms. J. mar. Res. 12: $141-147$

Lane, J. W. (1975). Optical properties of salt ice. J. Glaciol. 15: $363-372$

Legendre, L., Legendre, P. (1984). Ecologie numérique, 2nd ed. 2. La structure des données écologiques. Masson, Paris, et Presses de l'Université du Québec, Québec

Levasseur, M., Therriault, J.-C., Legendre, L. (1983). Tidal currents, winds and the morphology of phytoplankton spatial structures. J. mar. Res. 41: 655-672

Lewis, M. R., Smith, J. C. (1983). A small volume, shortincubation-time method for measurement of photosynthesis as a function of incident irradiance. Mar. Ecol. Prog. Ser. 13: 99-102

Mackas, D. L. (1984). Spatial autocorrelation of plankton community composition in a continental shelf ecosystem. Limnol. Oceanogr. 29: 451-471

Maykut, G. A., Grenfell, T. C. (1975). The spectral distribution of light beneath first-year sea-ice in the Arctic Ocean. Limnol. Oceanogr. 20: 554-563

McConville, M. J., Wetherbee, R. (1983). The bottom-ice microalgal community from annual ice in the inshore waters of East Antarctica. J. Phycol 19: 431-439

Moran, P. A. P. (1950). Notes on continuous stochastic phenomena. Biometrika 37: 17-23

Platt, T., Gallegos, C. L., Harrison, W. G. (1980). Photoinhibition of photosynthesis in natural assemblages of marine phytoplankton. J. mar. Res. 38: 687-701

Poulin, M., Cardinal, A., Legendre, L. (1983). Réponse d'une communauté de diatomées de glace à un gradient de salinité (baie d'Hudson). Mar. Biol. 76: 191-202

Richardson, K., Beardall, J., Raven, J. A. (1983). Adaptation of unicellular algae to irradiance: an analysis of strategies. New Phytol. 93: 157-191

Sasaki, H., Watanabe, K. (1984). Underwater observations of ice algae in Lützow-Holm Bay, Antarctica. Antarct. Rec. 81: 1-8

Skellam, J. G. (1951). Random dispersal in theoretical populations. Biometrika 38: 196-218

Siegel, S. (1956). Nonparametric statistics for the behavioral sciences. McGraw-Hill, New York

Sokal, R. R. (1979). Ecological parameters inferred from spatial correlograms. In: Patil, G. P., Rosenzweig, M. L. (ed.) Contemporary quantitative ecology and related ecometrics. Statistical Ecology Series, Vol. 12. International Cooperative Publ. House, Fairland, Maryland, p. 167-196

Sokal, R. R., Oden, N. L. (1978). Spatial autocorrelation in biology. I. Methodology. Biol. J. Linnean Soc. Lond. 10: 199-228

Sokal, R. R., Rohlf, F. J. (1981). Biometry - The principles and practice of statistics in biological research. 2nd ed. W. H. Freeman and Co., San Francisco

Steele, J. H. (1978). Some comments on plankton patches. In: Steele, J. H. (ed.) Spatial pattern in plankton communities. Plenum Press, New York and London, p. 1-17

Strickland, J. D. H., Parsons, T. R. (1972). A practical handbook of seawater analysis, 2nd ed. Bull. Fish. Res. Bd Can. 167: $1-310$

Therriault, J.-C., Lawrence, D. L., Platt, T. (1978). Spatial variability of phytoplankton turnover in relation to physical processes in a coastal environment. Limnol. Oceanogr. 23: $900-911$

Yentsch, C. S., Menzel, D. W. (1963). A method for the determination of phytoplankton chlorophyll and phaeophytin by fluorescence. Deep Sea Res. 10: 221-231 